\title{
Genetic pattern of belt-wide petroliferous phenomenon in the eastern Pearl River Mouth Basin and its practical application
}

\author{
Shi Hesheng ${ }^{1}$, Dai Yiding ${ }^{1}$, Liu Lihua ${ }^{1 *}$, Shu Yu ${ }^{1}$ and Mei Lianfu ${ }^{2}$ \\ ${ }^{1}$ CNOOC China Limited-Shenzhen, Guangdong 510240, China \\ ${ }^{2}$ Key Laboratory of Tectonics and Petroleum Resources of Ministry of Education, China University of Geosciences, Wuhan, \\ Hubei 430074, China
}

(C) China University of Petroleum (Beijing) and Springer-Verlag Berlin Heidelberg 2014

\begin{abstract}
The Pearl River Mouth Basin (PRMB) covers an area of approximately $20 \times 10^{4} \mathrm{~km}^{2}$. However, oil-gas fields detected in this area thus far are highly concentrated and controlled predominantly by second-order structural belts, the seven largest of which aggregate proved oil reserves of $7.7 \times 10^{8} \mathrm{~m}^{3}$, accounting for $86 \%$ of the total discovered reserve in the basin. These second-order structures have one common phenomenon: oil is contained in all traps present in them. In other words, they are all belt-wide petroliferous reservoirs. Research has identified eight types of second-order structural belts under two categories in the eastern PRMB. Their petroliferous properties are subject to three typical constraints: petroliferous properties of subsags hosting these structural belts, locations of these belts in the petroleum system, and availability of traps prior to the hydrocarbon expulsion and migration. The formation and distribution of oil reservoirs in these belts are characterized by subsag-belt integration and "three-in-one". The former indicates that sags and the second-order structural belts within the supply range of the sags constitute the basic units of hydrocarbon accumulations and are therefore inseparable. The latter indicates that a belt-wide petroliferous second-order structural belt always contains three important elements: hydrocarbon richness, effective pathway and pre-existing traps.
\end{abstract}

Key words: Pearl River Mouth Basin, belt-wide petroliferous phenomenon, second-order structural belt, petroleum exploration

\section{Introduction}

The Pearl River Mouth Basin (PRMB) lies at the edge of the continent in the northern South China Sea, covering an area of $20 \times 10^{4} \mathrm{~km}^{2}$. As an extensional basin formed since the Cenozoic, it presents as a marine-over-continental, reservoir-over-source (continental source marine reservoir), depression-over-fault double-layered structure. Horizontally, it displays a three-uplift two-depression structural pattern comprising five structural units, which include, from north to south, the northern step-fault, northern depression, central uplift, southern depression and the southern uplift (Fig. 1). Exploration during the past three decades has identified 75 oil-gas fields and petroliferous structures in the eastern PRMB that aggregate proved oil reserves of $8.9 \times 10^{8} \mathrm{~m}^{3}$ and gas reserves of $1,600 \times 10^{8} \mathrm{~m}^{3}$. These oil-gas fields and petroliferous structures have relatively concentrated petroliferous intervals that occur mostly in the Miocene deltaic sandstone/mudstone assemblages. From the horizontal

*Corresponding author. email: liulh1@cnooc.com.cn

Received April 23, 2013 hydrocarbon distribution, the eastern PRMB is generally characterized by "oil-in-north, gas-in-south" and "clustering" distribution. That is, oil is typically discovered in and around the northern depression, whereas gas is mainly detected in and around the southern depression. Most oil-gas fields discovered thus far occur in clusters in the uplifts as well as the depressions. However, they are controlled by second-order rather than first-order structural belts. Moreover, different second-order structural belts display striking selectivity and imbalance in their petroliferous properties. Some structures are belt-wide petroliferous, whereas others are nearly barren. Methods to recognize such phenomena are highly significant for successful exploration and further detection of reserve potentials of hydrocarbon-rich regions. Although oil and gas in this area share similar generation, migration and accumulation regimes, they are unique in their respective characteristics and regularity. This paper mainly examines the distribution and regime of oil pooling in the eastern PRMB.

Many studies and theories have covered the regime of hydrocarbon pooling and hydrocarbon accumulation. In China, petroleum geologists have also built a series of mature theories during the past three decades on the regime of 


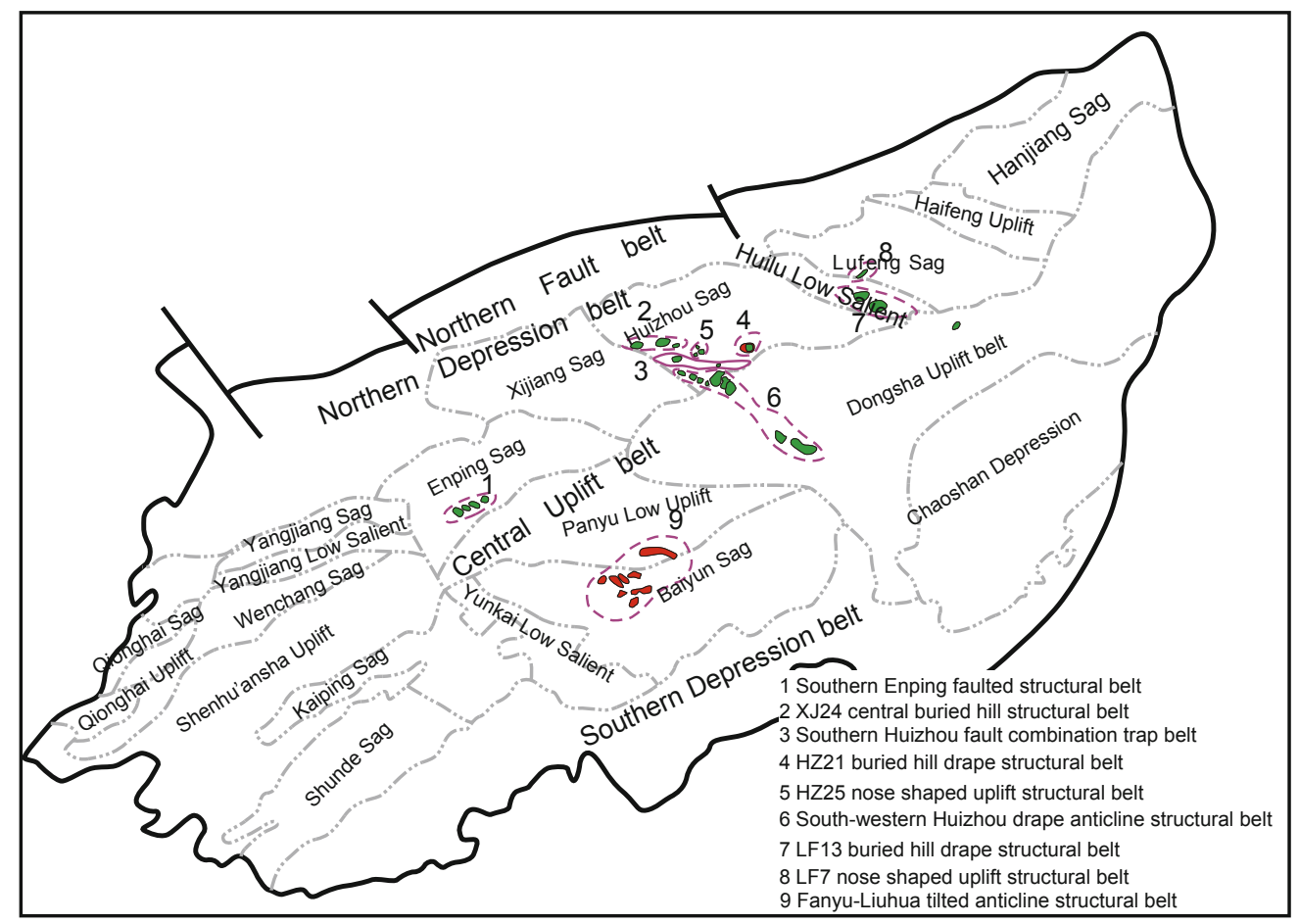

Fig. 1 Structural units and petroleum distribution in the Pearl River Mouth Basin

hydrocarbon accumulation in fault basins. These include the source control theory (Hu, 1982), which assumes that source regions control the distribution of oil-gas fields, and the composite hydrocarbon accumulation zone theory (Li, 1981; $\mathrm{Hu}$ et al, 1986), which emphasizes the temporal stacking and spatial compounding among various structural layers, as well as several petroliferous sequences and hydrocarbon accumulations. In recent years, breakthroughs have been achieved in hydrocarbon enrichment, pooling and exploration theories. Li and Pang (2001) introduced a series of new theories including fault-slope controlling sand deposition, complex transporting, multi-factor controlling oil and faciesfluid potential controlling pools. Liu et al (2006) proposed the theory of multi-factor controlling pools listing four primary pool-controlling factors of hydrocarbon migration pathways, fluid dynamics, reservoir critical properties and sandbody sealing. Zhu et al (2005) introduced the concept of composite hydrocarbon generation system. Demaison (1984) emphasized the accumulation control of source centers, which is similar to the source control theory of $\mathrm{Hu}$ (1982). The term "petroliferous system" introduced in the 1990s identifies that the generation, expulsion, transport and accumulation of oil and gas is a temporal and spatial domain that contains all geological elements and functions indispensable for the formation of oilgas reservoirs. Magoon and Dow (1994) suggested the use of four charts and one table to represent a petroliferous system. Paton et al (2008) classified petroliferous systems based on genesis according to source rock characteristics, migration manner and trap type. On this basis, the concept of "play", widely applied to target prediction and risk assessment in exploration communities, bridges the exploration targets between basins and traps (Beglinger et al, 2012), and from the perspective of structural belts, highlights the implications and value of second-order structural belts in exploration.
This confirms that structures acting as important constraints on hydrocarbon accumulation and enrichment control hydrocarbon pooling factors such as source rock (Klemme and Ulmishek, 1991; Lamaskin et al, 2008), reservoir caprock (Jackson and Galloway, 1984; McLeod et al, 2002; Lezzar et al, 2002; Li, 2004; Guillaume et al, 2008; Paton et al, 2008; Vakarelov and Bhattacharya, 2009; Su et al, 2011) and trap type (Biddle and Wielchowsky, 1994; Brenneke, 1995; Ambrose et al, 2005; Qi et al, 2008; Zou et al, 2011). In addition, they influence the sealing and transport capacity of a fault (Knott, 1993; Gibson and Bentham, 2003; An, 2009; Xiang et al, 2010; Tang and Cui, 2012). This determines the migration direction and accumulation pattern of oil and gas (Yu et al, 2009) and constrains the evolution of oil reservoirs (Hao et al, 2009; 2012; Langhi et al, 2010; Zhao et al, 2012; Zhu et al, 2012). Thus, the regime of hydrocarbon accumulation and its structural constraints are of paramount concern to exploration geologists (Xu et al, 2011). However, the aforementioned theories do not appear to be capable of accounting for the special hydrocarbon enrichment in the eastern PRMB.

Discussions on the regime of hydrocarbon accumulation in the PRMB began in the 1990s when the concept of structural ridge accumulating oil was conceived (Zou and Chen, 1991). Wang et al (2006) examined the hydrocarbon migration conditions in the PRMB and suggested that a three-dimensional networked step-like migration along the structural ridge line is the most striking feature of the hydrocarbon transport system in the PRMB. Cai et al (2009) agreed that hydrocarbon migration and accumulation in the PRMB is characterized by vertical migration in coordination with lateral migration, driven by hydrodynamic forces and buoyancy, with the later activity of faults playing a key role in hydrocarbon migration and accumulation into reservoirs. 
Although these outputs have guided exploration efforts in the PRMB in various periods, they cannot provide a satisfactory explanation for the extreme disparity in the richness of hydrocarbon accumulation. Thus, the authors conceived the belt-wide petroliferous theory after extended research into hydrocarbon exploration results and special hydrocarbon enrichment regime in the PRMB. This theory and its practical application are discussed herein.

\section{Belt-wide petroliferous phenomenon}

Although 36 second-order structural belts occur in the eastern PRMB, most of the discovered oilfields and petroliferous structures are contained in the seven largest second-order structural belts. These are the XJ24 central buried-hill structural belt, south-western Huizhou drape anticline structural belt, southern Huizhou fault combination trap belt, southern Enping faulted structural belt, LF13 buried-hill drape structural belt, Fanyu-Liuhua tilted anticline structural belt and the HZ25 nose-like uplift belt, in addition to a few less massive second-order structural belts such as LF7 and LH16 (Fig. 1). The controlled proved oil reserves are approximately $7.7 \times 10^{8} \mathrm{~m}^{3}$, accounting for $86 \%$ of the total discovered reserve. Furthermore, oil has been observed in all traps located in these second-order structural belts with the rare exception of some dry boreholes. These structures provide evidence that the distribution of oil-gas fields in this region is controlled by second-order structural belts and displays a belt-wide petroliferous phenomenon.

The term "belt-wide petroliferous" indicates the phenomenon that all traps within the supply range of hydrocarbon-rich subsags and on dominant hydrocarbon migration pathways exhibit hydrocarbon accumulation.

\section{Geological conditions and dominant constraints of belt-wide petroliferous phenomenon}

Exploration practices in East China have indicated that hydrocarbon migration and accumulation in fault basins are generally controlled by positive second-order structural belts within the basins. Hydrocarbon in fault basins of China creates various hydrocarbon pools with distribution controlled by fault-depressions in addition to the development characteristics of second-order structures within the fault basins (Fu and Yang, 2001). The "slope-belt nose-like structure accumulating oil" theory, in connection with the oil accumulation regime in half-graben depression slopebelt nose-like structures when summarizing exploration practices in the Erlian Basin and Central Hebei Depression, also signifies the understanding of the oil-controlling regime of second-order structural belts. This is also applied to the PRMB, where nearly all discovered oil-gas fields and petroliferous structures are located on various second-order structural belts that vary widely in oil-bearing properties controlled by the characteristics and type of structural belts, and geological factors such as the source, reservoir, caprock, trap, and migration and transport systems. The location of the second-order structural belts and their coupling with the hydrocarbon source kitchen are determinants of their oilbearing property.

\subsection{Positive structural belts as base sites for hydrocarbon accumulation}

A second-order structural belt contains many third-order structures, including other types of traps associated with these third-order structures, which are physically adjacent with the same genetic connection and a shared development history. Based on the formation time, the second-order structural belts in the eastern PRMB are categorized as follows: Paleogene second-order structural belts formed during rifting periods and Neogene second-order structural belts formed during depression periods.

\subsubsection{Paleogene second-order structural belts}

1) Buried-hill drape structural belts. The basement structural layer consists principally of paleogeomorphic buried hills which have monadnock geomorphology caused by denudation or paleo-buried hills formed from the basement due to tilted uplifting movement during faulting activity. Under differential compaction, the Paleogene deposition formed drape anticlines or lithologic-stratigraphic traps. Such structures are present both on steep and gentle slopes of dustpan subsags, the most typical of which are the HZ21 buried-hill drape structural belt (Fig. 2), the northern Enping buried-hill drape structural belt and the LF13 buried-hill drape structural belt (Fig. 6).

2) Paleo-uplift drape anticline structural belts. Paleogeomorphic highs formed from the basement that had remained weathered and denuded until the Neogene. The paleogeomorphology is represented by continuous mountains, under the continual transgression of the Neogene, the sedimentary caprocks onlap or are draped over them, resulting in lithologic-stratigraphic traps and drape anticlines. These structures occur on uplifts in basins, the most typical of which are south-western drape anticline structural belts (Fig. 3).

3) Nose-like uplift structural belts. Nose-like structures resulted from differential movement of faults. The paleogeomorphology of the basement structural layer is either tilting towards subsags or uplifting. Paleogene deposits onlapped or draped over these structures to form noselike uplift. Such structures are typically observed in the downthrown walls of faults at the lateral connection of sagcontrolling boundary faults and on gentle slopes between subsags. Their strikes are either diagonal or orthogonal to the subsags. The most typical are HZ25 (Figs. 2(a), 4) and LF7 nose-like uplift structural belts.

4) Tilted fault block structural belts. These occur most commonly on gentle slopes and are formed because of the activity of antithetic normal faults during fault depression periods. This group of faults dipped in the same direction and occurred at the same time as the boundary faults, cutting the basement into many tilted blocks. Movement stopped as the fault depression ended. Some of these faults may have been reactivated during neotectonic movement to create block mountains, drape anticlines, blocks or nose-like structures in the lower structural layer and growth anticlines and drag structures in the upper structural layer. A typical example is 
the southern Enping faulted structural belt (Fig. 5).

5) Central buried-hill structural belts. These are buried basement abrupt change belts spreading parallel to the axes of subsags. While the basin rifting period extended, the bedrock blocks tilted in a pushing extension, resulting in buried hills at the upper edge and fault depression at the lower fault edge, both of which were overlaid by rifting period deposits and became central buried-hill structural belts containing drape anticlines or lithologic-stratigraphic traps in the uplifted wall of the fault and reverse drag anticlines in the thrown wall of the fault. The most typical is the XJ24 buried-hill structural belt (Figs. 2(a), 7).

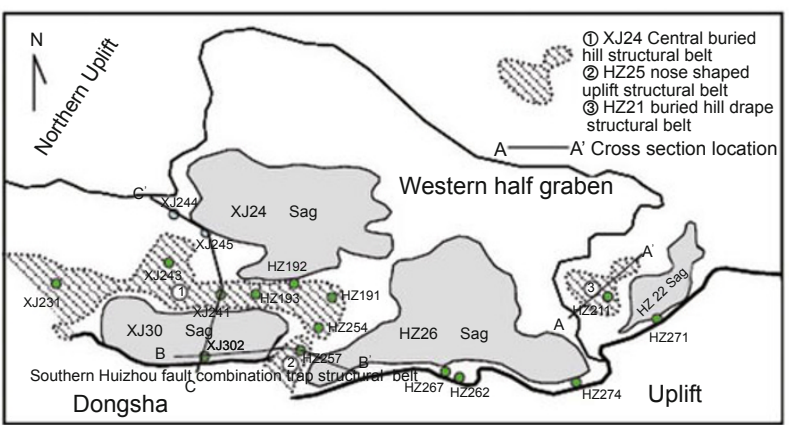

Fig. 2 (a) Distribution of structural units in the western Huizhou half graben

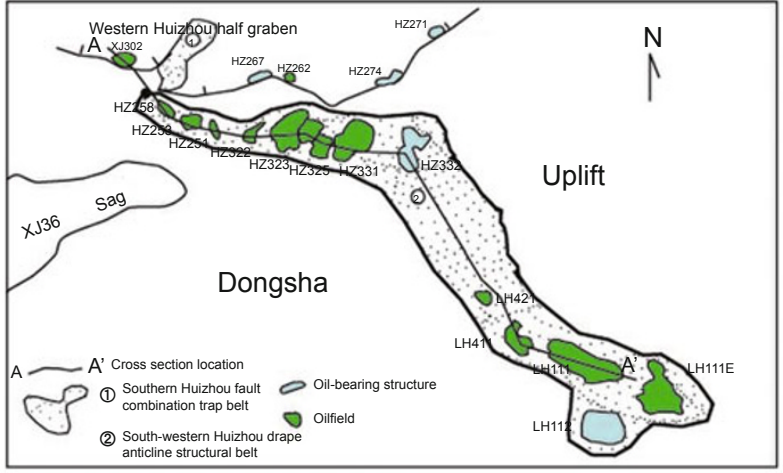

Fig. 3 (a) Distribution of structural units in the south-western Huizhou half graben

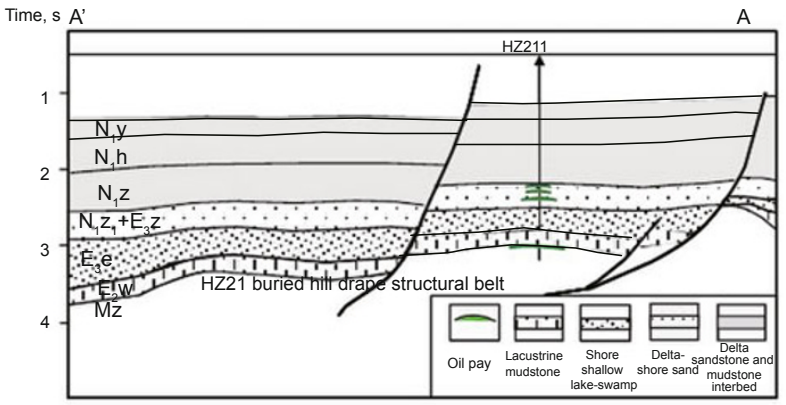

Fig. 2 (b) Geological profile of the HZ21 buried-hill drape structural belt

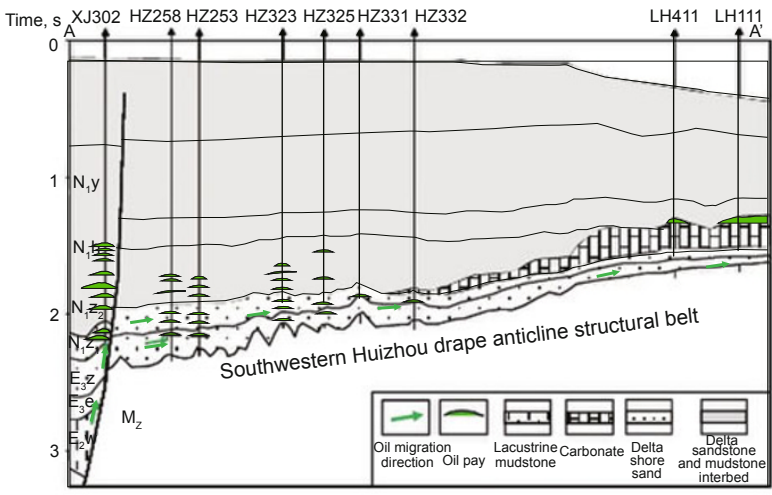

Fig. 3 (b) Geological profile of the southwestern Huizhou drape structural belt

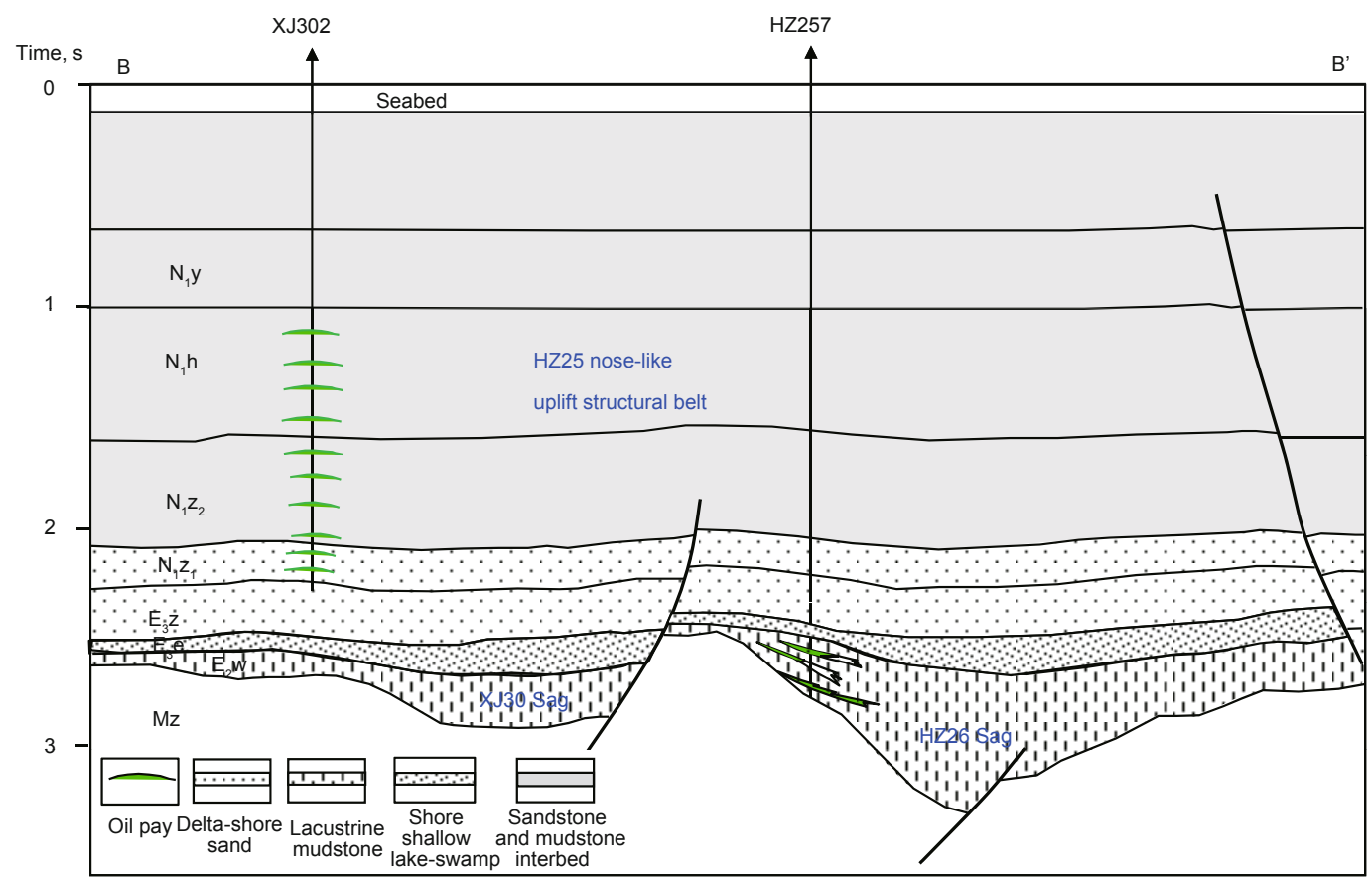

Fig. 4 Geological explanation profile of HZ25 nose-like uplift structural belt 


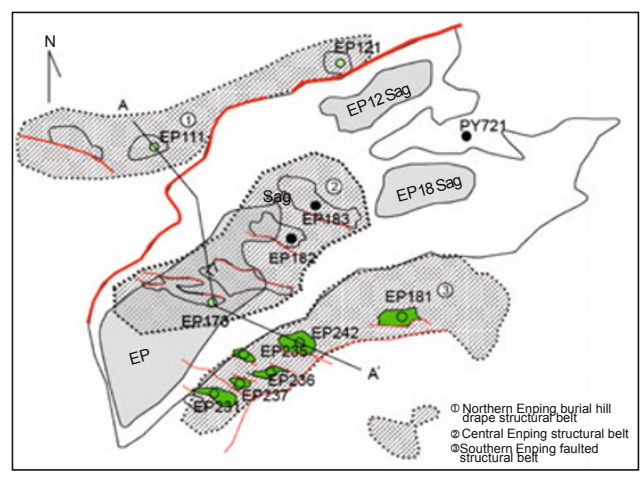

Fig. 5 (a) Distribution of structural units in the Enping Depression

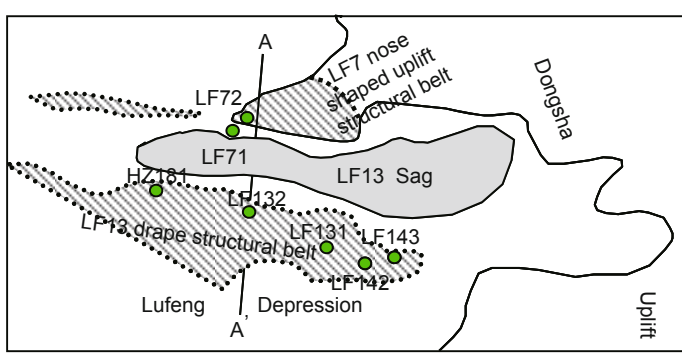

Fig. 6 (a) Distribution of structural units in the Lufeng Depression

6) Central arched anticline belts. These are located at the center of subsags and contain normal faults opposite to each other at the axis of anticlines in the shapes of lotus petals. These faults occur only in the Paleogene Formation and do not

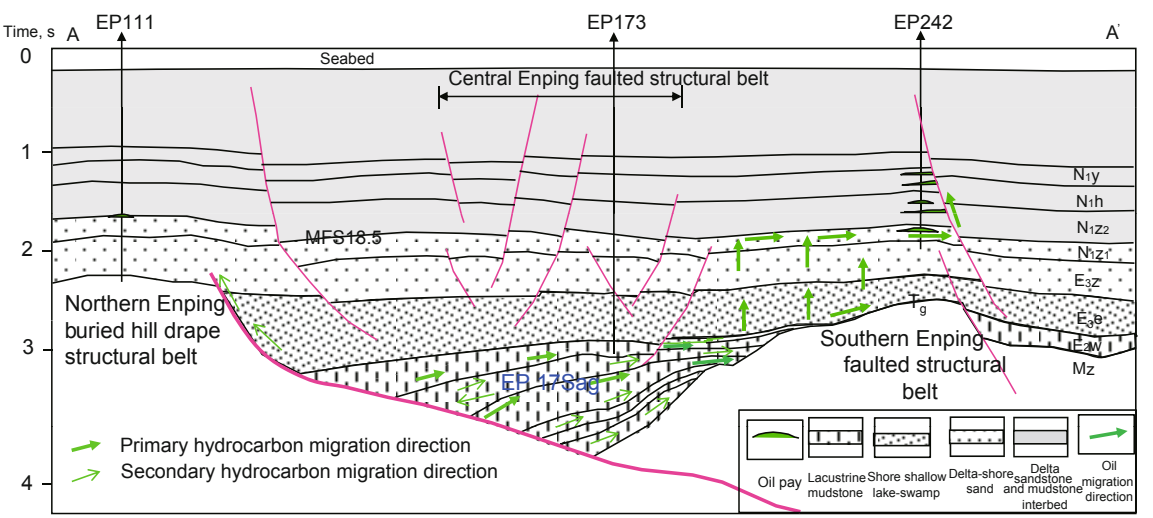

Fig. 5 (b) Geological profile across the Enping Depression

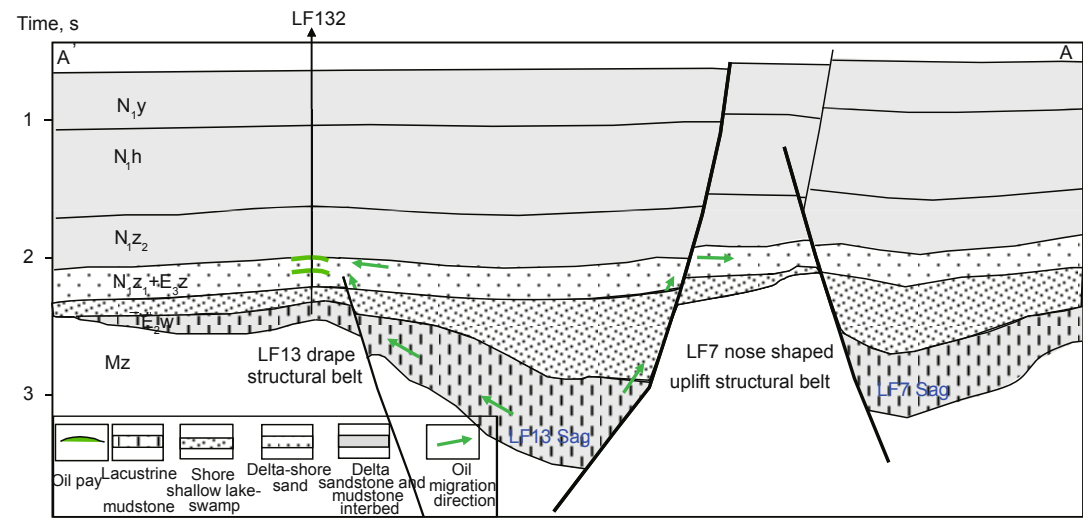

Fig. 6 (b) Geological profile across the Lufeng Depression

cut into the basement or the overlying Neogene Formation. Their genesis is related to gravity-induced pressure stress. The most typical are the HZ08 (Fig. 8) and KP11 arched anticline structural belts.

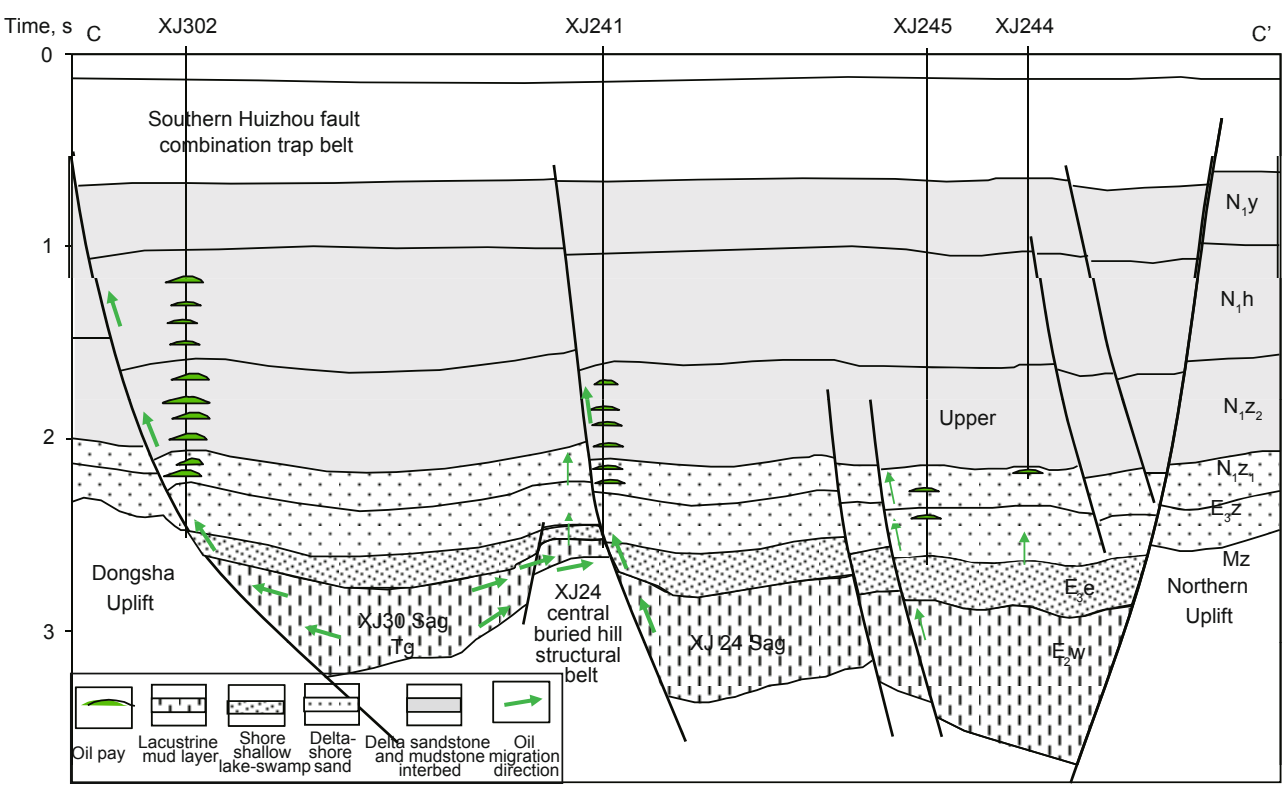

Fig. 7 Geological profile across the XJ24 central buried-hill structural belt 


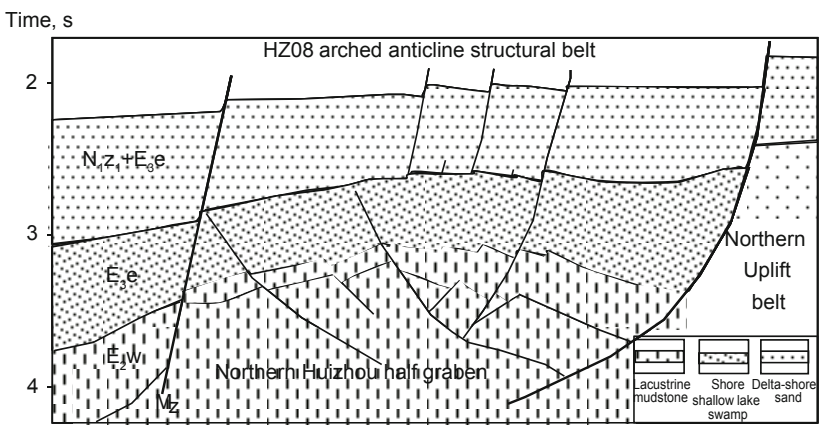

Fig. 8 Geological profile across the HZ08 arched anticline structural belt

\subsubsection{Neogene second-order structural belts}

1) Tilted anticline structural belts. Neotectonic movement, as represented by the Dongsha Movement, resulted in intense block elevation and subsidence in the PRMB, producing numerous NWW-SEE tensor-shear faults and activating several older faults. This process resulted in the formation of many tilted anticlines and block structures that are found in both subsags and uplifts (Sun et al, 2007). The most typical are the central Enping faulted structural belt (Fig. 5) and the Fanyu-Liuhua tilted anticline structural belt.

2) Growth anticline structural belts. Their distribution resembles strings of beads in the uplifted walls of boundary faults along their strikes. These are rollover anticlines that were deposited during rifting period boundary fault activation. The most typical include the southern Huizhou fault combination trap belt (Figs. 2(a), 3(a), 7) and the HZ22 rollover anticline belt.

\subsection{Second-order structural belts within the hydrocarbon supply range of hydrocarbon-rich sags have good petroliferous properties}

In the Paleogene, numerous fault basins and inter-basin uplifted ranges formed in the PRMB as an active structural belt at the eastern edge of the South China continent to compose a large regional basin-range structure. The three depressions in this structure contained 9 sags and 53 subsags. In these subsags, the primary source rock, the Wenchang Formation, developed during the rifting period of basin development. However, these subsags vary widely in source conditions. In the Zhu1 Depression, where the largest supply of hydrocarbon has been detected, only 14 of the 43 subsags include criteria of being hydrocarbon-rich (Chen et al, 2003). Table 1 shows the geochemical indicators of these subsags. All hydrocarbon-rich second-order structures are within the effective supply of these hydrocarbon-rich subsags. In the eastern PRMB, two types of hydrocarbon-rich subsags occur, Enping-type low-angle structures (Fig. 5(b)) and Huizhoutype high-angle structures (Fig. 7). These present: a) undercompensated depositional filling features as reflected by thicklayered deep lake gravity flow depositional assemblages, ample planktonic algae and specific biological marker compounds; b) composite nutrition water features represented by abundant plankton due to the rich nutrition matter provided by volcanic movement during the rifting period; c) depositional filling features corresponding to rifting cycles; $d$ ) extension and subsidence features represented by the paleofall of $>2,000 \mathrm{~m}$ and horizontal extension of $>4,000 \mathrm{~m}$ of the source rock sequence; e) good hydrocarbon-generating indicators; and f) singular and rapid episodic charging in the primary pooling period of the region.

3.2.1 Second-order structural belts on migration pathways have good petroliferous properties

Second-order structural belts become sites where hydrocarbon accumulates only if effective hydrocarbon migration pathway systems are present. For the eastern PRMB, the main transport systems are vertical, formed by faults, relay lateral transport systems developed by transgression sand bodies underlying regional caprock together with unconformity surfaces, and the step-like networked transport systems developed by faults underlying regional caprock together with interconnected sand bodies or unconformity surfaces. These systems constitute dominant hydrocarbon migration pathways.

For second-order structural belts located directly above hydrocarbon source kitchens, vertical transport systems formed by faults are the only pathways for hydrocarbon migration. Only second-order structural belts with oilsource faults can accumulate hydrocarbon. Otherwise, they become oil-poor due to the lack of a source pathway for accepting hydrocarbon even if they are located directly above hydrocarbon source kitchens. An example is the central

Table 1 Evaluation criteria of hydrocarbon generation potential of source rocks in main hydrocarbon-rich sags of the Zhu-1 Depression

\begin{tabular}{c|ccccc}
\hline Sag & XJ24 sag & HZ26 sag & LF13 sag & PY4 sag & EP17 sag \\
Sag area, km ${ }^{2}$ & 503 & 429 & 485 & 257 & 343 \\
Prototype thickness of the Wenchang Fm., m & 2200 & 2900 & 2500 & 2600 & 3600 \\
Residual thickness of the Wenchang Fm., m & 1700 & 2500 & 2200 & 2400 & 3100 \\
TOC (mean), \% & 1.99 & 2.21 & 3.2 & 4.51 & 1.07 \\
TOC (range, \%)/number of samples & $(1.39-2.53) / 11$ & $(0.76-3.59) / 12$ & $(1.93-7.75) / 12$ & $(0.78-11.43) / 93$ & $(0.88-1.45) / 6$ \\
S1+S2 (mean), mg/g & 3.68 & 5.71 & 13.9 & 22.32 & 1.23 \\
S1+S2 (range, mg/g)/number of samples & $(1.94-6.89) / 11$ & $(1.32-9.86) / 12$ & $(7.51-28.82) / 12$ & $(1.45-87.35) / 93$ & $(0.59-2.55) / 6$ \\
Type of organic matter & Mainly II 2 & Mainly II 2 & Mainly II $-\mathrm{II}_{2}$ & Mainly I-II & Mainly II 2 \\
\% of high-quality source rock & $/$ & 8 & 35 & 70 & / \\
\% of good source rock & 45 & 58 & 55 & 20 & $/$ \\
\hline
\end{tabular}


Enping faulted structural belt (Fig. 5).

A relay lateral transport system comprises regional caprock and transgression sand bodies underlying the caprock together with unconformity surfaces. The $18.5 \mathrm{Ma}$ mass transgressions resulted in widespread regional marine flooding mudstones in the basin and became the roof of hydrocarbon migration. Underlying it are transgression sand bodies beneath the late Oligocene-early Miocene Zhuhai Formation-Zhujiang Formation. Permeable formations of various ages were connected laterally into a transport network and ascended level by level from subsags to uplifts to create dominant hydrocarbon migration pathways. An example is the southern Enping faulted structural belt (Fig. 5).

A step-like transport system comprises interconnected sand bodies underlying regional caprock together with faults. The transport sequences underlying the marine flooding mudstones correspond to three largest marine flooding surfaces in the PRMB (MFS 18.5, MFS 17.0 and MFS 16.0) and these transport sequences constitute the dominant hydrocarbon migration pathways. Hydrocarbon expelled from the source rock entered the transport layers underlying the regional caprock (MFS 18.5 Ma marine flooding mudstones) and migrated towards the second-order structural belts in the low-potential regions, ascending level by level through faults into the overlying younger transport sequences and gathering on the second-order structural belts. The southern Huizhou drape anticline structural belt (Fig. 3) and the LF13 buriedhill drape structural belt (Fig. 6) are both typical examples of such transport systems.

A hydrocarbon gathering unit is a geological body with relatively independent hydrocarbon migration and accumulation systems but the same hydrocarbon migration indicators. It is a geological unit accommodating the entire process of hydrocarbon migration and accumulation identified by a group of hydrocarbon migration and accumulation flow lines and delineated by hydrocarbon migration troughs and external hydrocarbon migration boundaries. Second-order structural belts are low-potential regions inside the gathering units and are indicators for hydrocarbon migration. As can be inferred from the gathering volume and gathering abundance of the gathering units in the main oil production area of the Zhu1 Depression (Table 2), all Type I gathering units are controlled by hydrocarbon-rich subsags and are located within the effective supply range of hydrocarbon-rich subsags. Only the second-order structural belts in the Type I gathering units are hydrocarbon enrichment zones.

Table 2 Evaluation of gathering units in the eastern PRMB

\begin{tabular}{|c|c|c|c|c|c|}
\hline No. & Hydrocarbon gathering unit & Area, $\mathrm{km}^{2}$ & $\begin{array}{c}\text { Gathering } \\
\text { volume, } 10^{8} \mathrm{t}\end{array}$ & $\begin{array}{l}\text { Gathering abundance, } \\
10^{4} \mathrm{t} / \mathrm{km}^{2}\end{array}$ & Grade \\
\hline 1 & HZ6 tilted structural belt & 373 & 0.311 & 8.34 & III \\
\hline 2 & LF7 nose-like uplift belt & 332 & 1.549 & 46.65 & I \\
\hline 3 & LF13 tilted fault block belt & 2765 & 8.02 & 29.01 & I \\
\hline 4 & HZ08 arched anticline belt & 1448 & 2.83 & 19.56 & II \\
\hline 5 & $\begin{array}{l}\text { HZ14 buried-hill drape } \\
\text { structural belt }\end{array}$ & 407 & 0.265 & 6.5 & III \\
\hline 6 & $\begin{array}{l}\text { HZ21 buried-hill drape } \\
\text { structural belt }\end{array}$ & 625 & 5.5 & 87.98 & I \\
\hline 7 & $\begin{array}{c}\text { Southern Huizhou } \\
\text { combination trap belt } \\
\text { (including southwestern Huizhou drape anticline structural belt) }\end{array}$ & 2681 & 10.62 & 39.62 & I \\
\hline 8 & Southern HZ13 tilted structural belt & 478 & 1.257 & 26.3 & II \\
\hline 9 & Central XJ24 buried-hill belt & 689 & 5.97 & 86.58 & I \\
\hline 10 & XJ17 nose-like uplift belt & 1043 & 0.176 & 1.69 & III \\
\hline 11 & $\begin{array}{l}\text { XJ27 buried-hill drape } \\
\text { structural belt }\end{array}$ & 670 & 0.789 & 11.78 & III \\
\hline 12 & FY3 buried-hill drape structural belt & 2796 & 8.26 & 29.32 & I \\
\hline 13 & FY9 tilted structural structural belt & 1109 & 0.183 & 1.65 & III \\
\hline 14 & $\begin{array}{l}\text { Northern Enping drape } \\
\text { structural belt }\end{array}$ & 1604 & 0.657 & 4.1 & III \\
\hline 15 & $\begin{array}{l}\text { Central Enping faulted } \\
\text { structural belt }\end{array}$ & 2279 & 2.93 & 12.86 & II \\
\hline 16 & $\begin{array}{l}\text { Southern Enping faulted } \\
\text { structural belt }\end{array}$ & 1537 & 4.267 & 27.76 & I \\
\hline
\end{tabular}


The prevailing migration direction of hydrocarbon in a formation is decided by the attitude of the permeable formation. That is, it is controlled by the migration pathways and by hydrodynamic force direction and hydrocarbon buoyancy direction (Pang et al, 2005). Under static water conditions, the up-dip direction of the carrier is the indicator of hydrocarbon migration. In the PRMB, the attitude of the source sequence exhibits control on the direction of hydrocarbon migration which is towards the up-dip of the source layer. Only second-order structural belts located in this direction can have hydrocarbon accumulation or enrichment.

3.2.2 Second-order structural belts with reservoir-caprock coincidence have good petroliferous properties

The dominant accumulation sequence in the eastern PRMB is marine deposits developed under continued transgression in the depression period, which includes the late Oligocene Zhujiang Formation transitional-shore shallow lake sandstone/mudstone assemblage and the Miocene Zhujiang Formation-Yuehai Formation marine deltaic sandstone/mudstone assemblage. The sandstone has extremely good reservoir properties. Minerals in the Zhuhai Formation sandstones are dominantly quartz, which accounts for more than $85 \%$. Other characteristics are medium-to-good sorting and medium roundness with microscopic surface porosity of 15\%-20\% and unit thickness of 3-7 $\mathrm{m}$ (Zhu et al, 2010). The Zhujiang Formation-Hanjiang Formation deltaic sandstone, with a porosity of greater than $22 \%$ and a permeability of generally $(800-3,000) \times 10^{-3} \mu^{2}$, consists mainly of mediumcoarse sandstone of acceptable sorting and roundness (Zhu et al, 2010). The caprock contains regional caps resulting from delta lobe swing and channel migration and regional marine flooding mudstone resulting from sea level fluctuation. Over the three largest marine flooding surfaces of MFS 18.5, MFS 17.0 and MFS 16.0, mudstone is concentrated and constitutes a good reservoir-caprock assemblage with the underlying low-stand system tract and transgression system tract sandstones.

\subsubsection{Second-order structural belts with traps formed before hydrocarbon expulsion peaks have good petroliferous properties}

Only traps formed before the critical time of accumulation are effective for capturing and gathering hydrocarbon. Traps formed after hydrocarbon expulsion peaks are unfavorable for hydrocarbon enrichment. In the PRMB, typical traps include drape anticlines, rollover anticlines, tilted fault anticlines, faulted noses, fault blocks, buried hills and reef traps on uplift belts. Except for drape anticlines and buried hills, which are older structures formed on base rock uplifts, all traps have genetic connections with faulting events. Faulting events in the PRMB occurred in three stages: 1) early faulting formed before the Miocene but not active since then; 2) late faulting formed after the Miocene, and 3) long-term faulting dated to the beginning of extension and still active after the Miocene. Early faulting is represented by extensional structural deformation that results in fault depression, whereas trap-controlling faulting associated with the formation of local structures mainly includes late and long-term faulting activities. Late faulting includes numerous tensor-shear faults resulting from the late Miocene Dongsha Movement and fault trap local structures associated with these faults including tilted half anticline, faulted nose and block. Long-term faulting is represented by extension in early stage and tension-shear in the late stage. The extension in the early stage controlled the depositional filling of the fault depressions, and the tension-shear strike slip in the late stage created numerous growth anticlines such as rollovers, faulted noses and half anticlines. The Dongsha Movement period is the main development period of local PRMB structures. The Dongsha Movement reformed the older drape anticlines and caused the formation of the anticlines and half anticlines in both walls of the faults. Hence, while local structures produced by these two suits of fault systems formed in different stress settings and periods, they were eventually affected by the Dongsha Movement, and therefore had the same accumulation period as that in the eastern PRMB (10$0 \mathrm{Ma})$. As a result, the local structures in the eastern PRMB were formed prior to the accumulation period, which provided optimal conditions for capturing and gathering hydrocarbon, forming an important base for the belt-wide petroliferous phenomenon.

Subsags with high hydrocarbon expulsion intensities are conducive to petroleum accumulation. The PRMB has been in an extensional setting since the Cenozoic, when it underwent rifting, post-faulting fault-depression conversion and a thermo-subsidence depression period (Sun et al, 2011). However, major depositional hiatuses occurred only in the fault-depression conversion period before maturation of the Paleogene dominant source rocks. Therefore, the thermal evolution of organic matter is fairly simple. The basin modelling of the maturity evolution of organic matter in source rocks demonstrates that the thermal evolution and hydrocarbon generation and expulsion of organic matter in the two main source rock systems, the Wenchang and Enping Formations, were continuous processes. Hydrocarbon generation and expulsion began at 16-10 Ma and reached a peak at $10-5 \mathrm{Ma}$ (Fig. 9). According to the ${ }^{40} \mathrm{Ar}-{ }^{39} \mathrm{Ar}$ dating of authigenic illite from various pay intervals of drilled wells in the basin, the PRMB has undergone only one stage of accumulation, at approximately $10 \mathrm{Ma}$ (Table 3 ). The datum displays a typical late hydrocarbon concentration event from the Paleogene to the Neogene under the control of the late Miocene Dongsha Movement, which was characterized by rapid, simultaneous charging of multiple layers. Such pooling enabled an increase in the proportion of hydrocarbons available for accumulation, minimized hydrocarbon losses during the pooling process and producing high-efficiency hydrocarbon accumulation, which also helped to create the belt-wide petroliferous phenomenon.

\section{Genetic pattern of belt-wide petroliferous phenomenon}

The prerequisite for the belt-wide petroliferous phenomenon in the eastern PRMB is that the secondorder structural belts include all aforementioned geological conditions; the key is the manner in which these conditions are matched, coupled and correlated. After examining 

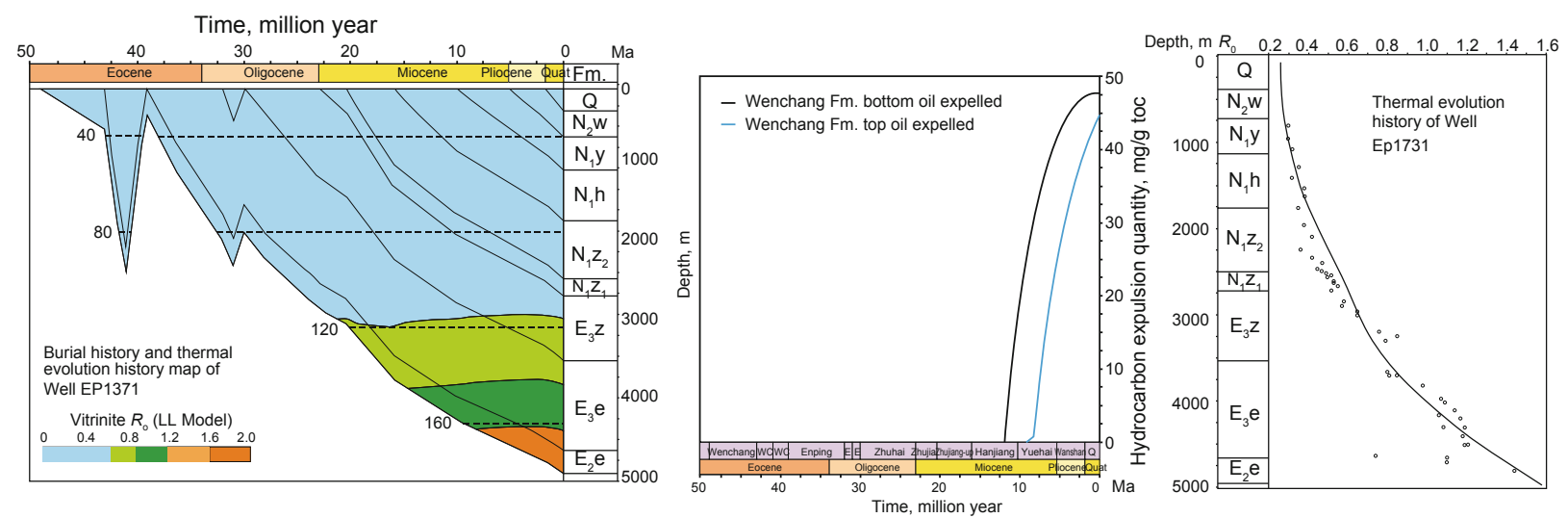

Fig. 9 Thermal evolution modeling curve of organic material in Well EP1731

Table 3 Authigenic illite ${ }^{40} \mathrm{Ar}-{ }^{39} \mathrm{Ar}$ dating data of typical reservoirs in the PRMB

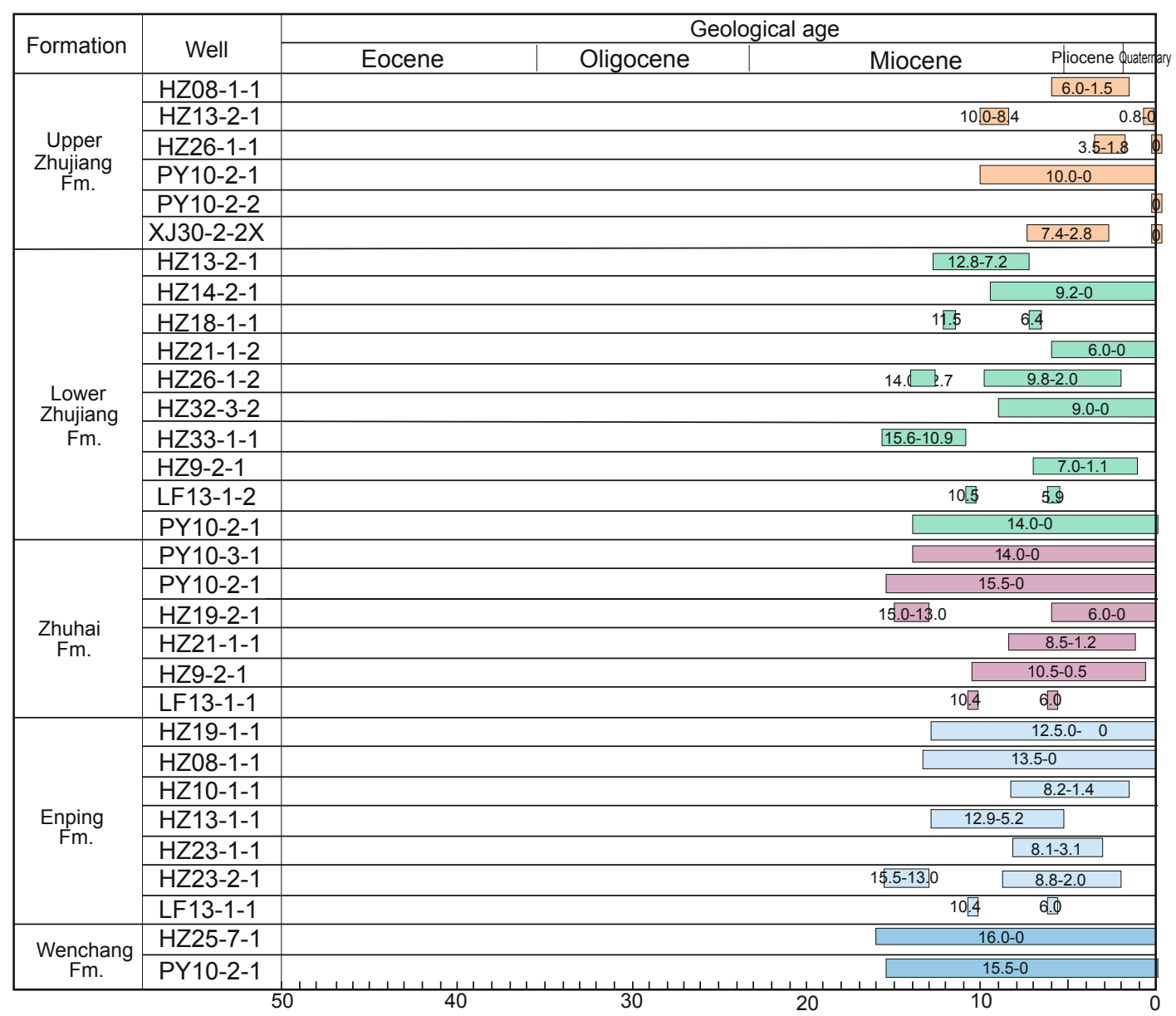

numerous second-order structural belts, we have determined the genetic pattern of the belt-wide petroliferous phenomenon in the eastern PRMB.

Because no major tectonic revolution has occurred in the tectonic evolution of the PRMB, its tectonic pattern shows good succession from old to new structures. The second-order structural belts formed during fault depression, including central buried-hill, paleo-uplift drape and tilted fault nose structural belts, and the rollover anticline structural belts resulting from long-term faulting activities have long been low-potential regions (Fig. 10), making them favorable indicators of hydrocarbon migration. In addition, because three suites of marine flooding mudstones, MFS 18.5, MFS 17.0 and MFS 16.0, are widely distributed across the basin, they are very stable regional caprocks that reduced hydrocarbon dispersion from the source to the accumulation sites. Thus, hydrocarbon in this region underwent highefficiency migration in excellent accumulation conditions. The second-order structural belts located in hydrocarbon accumulation units of rich hydrocarbon-generating sags, however, vary extraordinarily in their hydrocarbon enrichment under the joint control of the troughs of the source rock dominant pathways and the high-efficiency transport network made up of marine formations. The second- 
order structural belts located on the dominant hydrocarbon migration pathways (Pang, 2003) have low fluid potentials and a significant effect on hydrocarbon accumulation. Examples include Subsag A and Subsag B in the hydrocarbon accumulation pattern of the eastern PRMB (Fig. 10), in which the source rock formation occurrence has an intense control on the hydrocarbon accumulation in second-order structural belts. In Subsag B, the source rock formation dips up from the subsag center towards the steep slope belt and gentle slope belt, enabling the hydrocarbon generated from it to migrate towards the steep slope and gentle slope along the respective dominant pathways. As a result, the hydrocarbon supply is abundant, and hydrocarbons are highly enriched in the secondary structural belts in these two directions, which include rollover anticline, central buried-hill, drape anticline and tilted fault nose structural belts, such as the previously described southwestern Huizhou drape anticline structural belt and the XJ24 central buried-hill structural belt (Figs. 2, 7). In Subsag A, the source rock formation slopes upward towards the gentle slope, and the dominant hydrocarbon migration direction is towards the gentle slope side, making it impossible for hydrocarbon migrate to the steep slope side. As a result, the tilted fault nose structural belts in the gentle slope direction have very good conditions for hydrocarbon accumulation. The steep slope side is not in the dominant hydrocarbon migration direction and is therefore unable to receive a substantial amount of hydrocarbon accumulation. This effect is evidenced by the extraordinary difference in hydrocarbon accumulation between the southern and northern parts of the Enping Sag. Many oilfields have been detected in the southern Enping faulted structural belt located on the gentle slope side, whereas no massive hydrocarbon accumulation has been detected in the northern Enping buried-hill drape structural belt located on the steep slope side (Figs. 5, 10).

For hydrocarbon-rich subsags, second-order structural belts located on dominant hydrocarbon migration pathways are conducive to hydrocarbon enrichment and often display a belt-wide petroliferous phenomenon. The Neogene central tilted fault nose structural belts located in the subsag center on the other side are second-order structural belts formed during the Neotectonic Movement-Dongsha Movement. Although these belts occur near the source, they lack the background of Paleogene structural highs and have poor conditions for hydrocarbon accumulation. Therefore, these belts cannot accumulate a substantial amount of hydrocarbon regardless of their location above a subsag. The hydrocarbon enrichment in subsags is not as favorable as that in elevated or uplifted regions, which may be attributed to the joint control of the accumulation in the secondary structural belts and the highefficiency transport network, which is a unique phenomenon in the Zhu1 Depression in the PRMB. If faulting activity fails to reach the source rock, no hydrocarbon will be present at that location even if the trap conditions are good because no migration pathway exists, such as the case of the central tilted fault nose structural belt illustrated in Fig. 10. Examples include the central rollover anticline and the Central Enping faulted structural belts in the Enping Sag (Fig. 5). The former exhibits several pay zones in XJ244 and XJ245 (Fig. 10), whereas the latter has been dry in two wells drilled thus far.

As previously discussed, the genetic pattern of the beltwide petroliferous phenomenon can be outlined as subsagbelt integration and "three-in-one".

The former indicates that subsags and the second-order structural belts within the hydrocarbon supply range of these subsags constitute the base units of hydrocarbon accumulation and are therefore hardly separable. Hydrocarbon will not accumulate and form an enrichment pool in a subsag if it is not accompanied by a positive second-order structural unit. Moreover, hydrocarbon will not enrich a belt if it is not accompanied by a subsag because the material base of hydrocarbon is only provided in subsags. Therefore, subsagbelt integration is a fundamental geological condition for the belt-wide petroliferous phenomenon.

"Three-in-one" is the genetic mechanism for the belt-wide petroliferous phenomenon. The "three" signifies three critical constraints on this phenomenon: hydrocarbon richness, effective pathways and prior trap formation. Hydrocarbon richness refers to good source conditions inside the subsag, where the source rock has high oil generation and expulsion

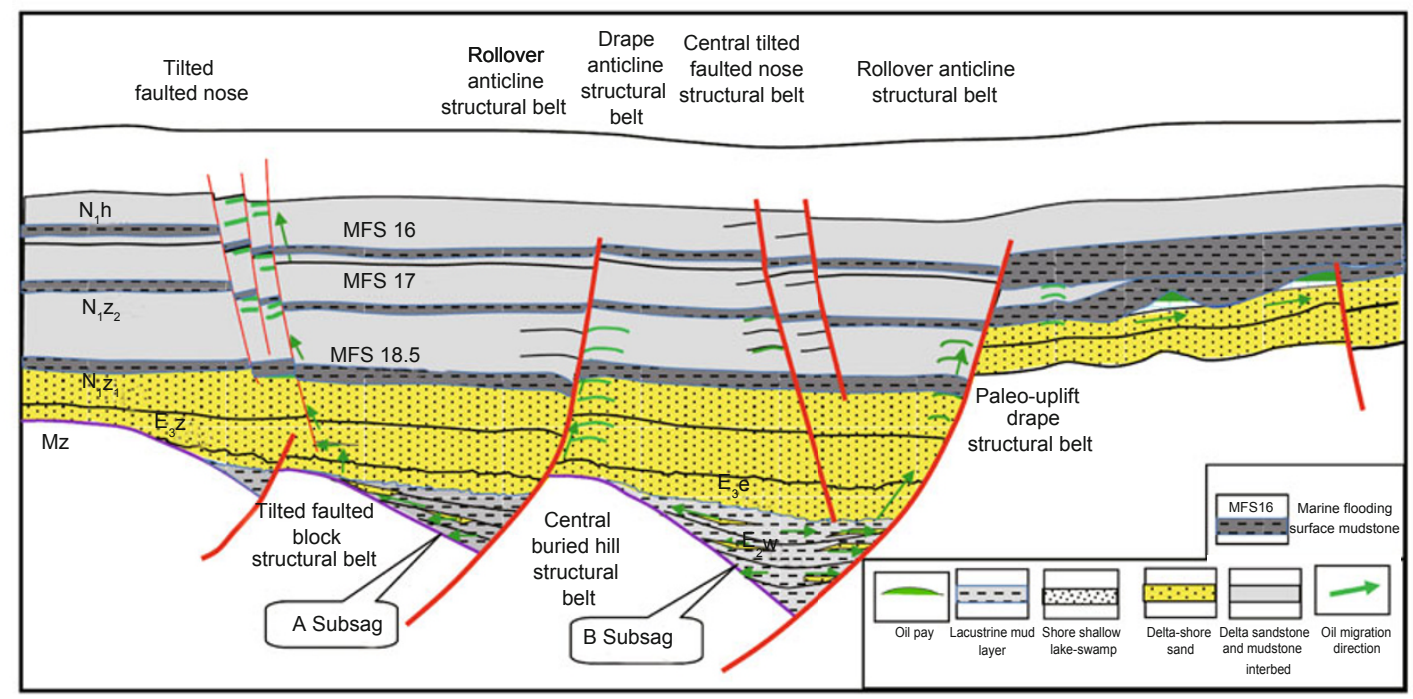

Fig. 10 Model of hydrocarbon-rich structural belt in the eastern PRMB 
intensity and the subsag is qualified as hydrocarbon-rich subsag. Effective pathways require that the positive secondorder structural belts in the subsag occur on dominant migration pathways in the hydrocarbon transport system so that hydrocarbon can migrate continuously from the hydrocarbon source kitchen into the trap. Prior trap formation indicates that traps in the second-order structural belts have formed no later than the time of the hydrocarbon generation and expulsion peak; otherwise, a substantial amount of hydrocarbon will not accumulate. Therefore, "three-in-one" indicates a belt-wide petroliferous second-order structural belt that contains all three critical elements: hydrocarbon richness, effective pathways and prior trap formation.

\section{Application of belt-wide petroliferous genetic patterns to petroleum exploration in the eastern PRMB}

The genetic pattern of belt-wide petroliferous phenomenon is an inference drawn from exploration in the second-order structural belts in the eastern PRMB and is successfully applied to exploration practice, confirming that this theoretical pattern is both functional and effective. This pattern may be used to guide exploration by the following procedure: Locate a hydrocarbon-rich subsag, identify the hydrocarbon transport system and dominant migration pathways in this subsag, and determine second-order structural belts on these dominant migration pathways that have traps formed prior to the peak hydrocarbon generation and expulsion period. The final procedure is to drill into traps in "three-in-one" second-order structural belts. The following are examples of theoretical genetic patterns used in exploration practices.

1) XJ24 central buried-hill structural belt. This belt, $56 \mathrm{~km}$ long and 3-8 km wide, lies in the middle of the oilrich sag known as the western Huizhou half graben, which stretches in the EW direction. The basement comprises a paleo-buried hill produced by tilting of the bedrock block in the pushing extension during fault depression. The overlying formation contains numerous structural traps such as drape anticlines, rollover anticlines and tilted fault anticlines. Seven oilfields of various sizes, including XJ231, XJ243 and HZ254, have been detected and have total proved oil reserves of $1.2 \times 10^{8} \mathrm{~m}^{3}$, which is $14 \%$ of the total oil reserve of the eastern PRMB. With the exception of structures that are too small to be economic, the structural traps have been drilled, and hydrocarbon has been detected in each structure, which demonstrates a prominent belt-wide petroliferous phenomenon. On the northern side including XJ244 and XJ245, reverse drag anticlines located in oil-generating subsags and resulting from late faulting activities do not have a significant effect on hydrocarbon accumulation because they are not developed on the Paleogene second-order structural belts. Only sporadic pays have been detected, and many traps either contain no oil or have low degrees of filling. These conditions differ significantly from the sufficient hydrocarbon charging and high charging intensity of the XJ24 buried-hill structural belt (Figs. 2, 7).

2) LF13 drape structural belt. This belt is $50 \mathrm{~km}$ long and
3-8 m wide, stretching NWW. It occurs on the gentle slope of the oil-rich LF13 subsag on a paleo-buried hill produced by tilting of the bedrock block caused by antithetic faulting in the Paleogene rifting period. Typical traps include buriedhill drape anticlines, with some tilted fault anticlines resulting from late rifting. Five structures have been drilled, of which LF131 and LF132 proved a total reserve of 5,000 $\times 10^{4} \mathrm{~m}^{3}$. The remaining three are oil-bearing structures and have small reserves attributed to the trap conditions. However, each structure on this belt contains oil, fulfilling the effective coverage of traps. One oil pay of LF131 i.e. Layer 2500, has a proved reserve of more than $1,600 \times 10^{4} \mathrm{~m}^{3}$ and a high degree of filling (Fig. 6).

3) Southwestern Huizhou drape anticline structural belt. This zoned paleogeomorphic high was produced by the bedrock overlying the paleo-uplift known as the Dongsha Uplift. Situated diagonally to the western Huizhou half graben in the source region and stretching NE-SW, this belt is $50 \mathrm{~km}$ long and approximately $20 \mathrm{~km}$ wide. It remained weathered and denuded until the Neogene before the deposited caprock onlapped or draped over it in the background of continuous Neogene transgression. This structural belt contains 20 traps of various descriptions including drape anticlines, lithologicstratigraphic and biogenic reef traps, where nine oilfields represented by HZ261 and LH111 and six oil-bearing structures have been detected with proved reserves of nearly $3.2 \times 10^{8} \mathrm{~m}^{3}$, accounting for $36 \%$ of the total proved oil reserve of the basin (Fig. 3).

4) Three structural belts in the Enping Sag. The Enping sag is a north-fault south-dip half graben that contains, from north to south, a northern buried-hill drape belt, a central tilted anticline structural belt and a southern faulted structural belt (Fig. 5(a)). The southern Enping faulted structural belt is $30 \mathrm{~km}$ long and $5-17 \mathrm{~km}$ wide. It is located on the gentle slope of the Enping Sag, where the basement is a paleo-buried hill produced by tilting of the bedrock block caused by faulting in the Paleogene rifting period. The overlying formation consists of numerous tilted fault nose structures resulting from late faulting activities. Hydrocarbon has been detected in all drilled seven structures, and five oilfields, as represented by EP242, have been discovered with proved reserves of more than $5,000 \times 10^{4} \mathrm{~m}^{3}$ (Fig. 5). The central Enping faulted structural belt occurs directly above the dominant hydrocarbon source kitchen in the Enping Sag. Physically, it appears to be the most favorable hydrocarbon accumulation region. On this belt local structures contemporaneous to and having similar genesis and features to those on the southern Enping faulted structural belts are distributed. Four wells have been drilled in this region, however, they are either dry or exhibit only sporadic hydrocarbon. These conditions differ significantly from those of the hydrocarbon-rich southern Enping faulted structural belt, the main reason for which may be the lack of source-bridging faults (Fig. 5). The northern Enping buried-hill drape structural belt belongs to the Paleogene buried-hill drape structural belt family. The source layer inside the subsags and the interlayer unconformity surfaces acting as transporters slope southwards up towards the gentle slope, and the dominant pathway points to the 
south side. Therefore, this northern structural belt is not in the prevailing direction of hydrocarbon migration, which explains the limited pays and hydrocarbon accumulation in two drilled wells (Fig. 5).

\section{Conclusions}

1) Eight types of second-order structural belts of two categories are contained in the eastern PRMB. These belts are found to vary tremendously in their petroliferous properties. Some are lean, whereas others display a belt-wide petroliferous phenomenon.

2) Principal constraints on the petroliferous properties of the second-order structural belts in the eastern PRMB include a) source conditions of subsags hosting these structural belts, b) locations of the second-order structural belts in the hydrocarbon system and c) traps which predate the time of hydrocarbon accumulation.

3) The genetic pattern of the belt-wide petroliferous phenomenon for the second-order structural belts in the eastern PRMB is subsag-belt integration and "three-inone". The former emphasizes that second-order structural belts contained in subsags are prerequisite for belt-wide petroliferous phenomenon. The latter signifies that a beltwide petroliferous second-order structural belt always includes all three critical elements: hydrocarbon richness, effective pathways and traps formed prior to the period of accumulation.

4) The hydrocarbon distribution and enrichment regime in the eastern PRMB is examined with a special focus on numerous structural belts including the XJ24 central buriedbelt drape structural belt, the LF13 buried-hill drape structural belt and the southwestern drape anticline structural belt. The belt-wide petroliferous theoretical pattern has been proposed and successfully used to guide hydrocarbon exploration in the Enping Sag, which further confirms the workability and effectiveness of this pattern.

\section{References}

Ambrose W A, Wawrzyniec T F, Fouad K, et al. Neogene tectonic, stratigraphic, and play framework of the southern Laguna MadreTuxpan continental shelf, Gulf of Mexico. AAPG Bulletin. 2005. 89(6): 725-751

An L Y. Paleochannel sands as conduits for hydrocarbon leakage across faults: An example from the Wilmington oil field, California. AAPG Bulletin. 2009. 93(10): 1263-1279

Beglinger S E, Corver M P, Doust H, et al. A new approach of relating petroleum system and play development to basin evolution: An application to the conjugate margin Gabon coastal and AlmadaCamamu basins. AAPG Bulletin. 2012. 96(6): 953-982

Biddle K T and Wielchowsky C C. Hydrocarbon traps. In: Magoon L B and Dow W G (eds.), The Petroleum System-from Source to Trap. AAPG Memoir 60. 1994. 219-235

Brenneke J C. Analysis of fault traps. World Oil. 1995. 216(12): 63-71

Cai Z R, Xia B, Wan Z F, et al. Differences in hydrocarbon migration and accumulation between the Pearl River Mouth and the YinggehaiQiongdongnan basins on the northern margin of South China Sea. Natural Gas Industry. 2009. 29(11): 9-12 (in Chinese)

Chen C M, Shi H S, Xu S C, et al. The Formation Conditions of Tertiary Petroleum Accumulations in Pearl River Mouth Basin. Beijing:
Petroleum Industry Press. 2003. 101-149 (in Chinese)

Demaison G. The generative basin concept. Petroleum Geochemistry and Basin Evaluation. AAPG Special Volumes. 1984. 1-14

$\mathrm{Fu} \mathrm{G}$ and Yang M. Hydrocarbon accumulation and distribution in fault basins. Petroleum Geology \& Experiment. 2001. 23(4): 408-423 (in Chinese)

Gibson R C and Bentham P A. Use of fault-seal analysis in understanding petroleum migration in a complexly faulted anticlinal trap, Columbus Basin, offshore Trinidad. AAPG Bulletin. 2003. 87(3): 465-478

Guillaume B, Dhont D and Brusset S. Three-dimensional geologic imaging and tectonic control on stratigraphic architecture: Upper Cretaceous of the Tremp Basin (south-central Pyrenees, Spain). AAPG Bulletin. 2008. 92(2): 249-269

Hao F, Zhou X H, Zhu Y M, et al. Charging of the Neogene Penglai 19-3 field, Bohai Bay Basin, China: Oil accumulation in a young trap in an active fault zone. AAPG Bulletin. 2009. 93(2): 155-179

Hao F, Zhou X H, Zou H Y, et al. Petroleum charging and leakage in the BZ25-1 field, Bohai Bay Basin. Journal of Earth Science. 2012. 23(3): 253-267

$\mathrm{Hu} \mathrm{C}$ Y. Source bed controls hydrocarbon habitat in continental basin, east China. Acta Petrolei Sinica. 1982. 3(2): 9-13 (in Chinese)

$\mathrm{Hu}$ J Y, Xu S B and Tong X G. Formation and distribution of complex petroleum accumulation zones in Bohaiwan Basin. Petroleum Exploration \& Development. 1986. 13(1): 1-8 (in Chinese)

Jackson M P A and Galloway W E. Structural and Depositional Styles of Gulf Coast Tertiary Continental Margins: Application to Hydrocarbon Exploration. American Association of Petroleum Geologists Inc., Tulsa. 1984. 226

Klemme H D and Ulmishek G F. Effective petroleum source rocks of the world: Stratigraphic distribution and controlling depositional factors. AAPG Bulletin. 1991. 75(12): 1809-1851

Knott S D. Fault seal analysis in the North Sea. AAPG Bulletin. 1993. 77(5): 778-792

Lamaskin T A, Dorsey R J and Vervoort J D. Tectonic controls on mudrock geochemistry, Mesozoic rocks of Eastern Oregon and Western Idaho, U.S.A.: Implications for Cordilleran tectonics. Journal of Sedimentary Research. 2008. 78(12): 765-783

Langhi L, Zhang Y H, Gartrell A, et al. Evaluating hydrocarbon trap integrity during fault reactivation using geomechanical threedimensional modeling: An example from the Timor Sea, Australia. AAPG Bulletin. 2010. 94(4): 567-591

Lezzar K E, Tiercelin J-J, Le Turdu C, et al. Control of normal fault interaction on the distribution of major Neogene sedimentary depocenters, Lake Tanganyika, East African Rift. AAPG Bulletin. 2002. 86(6): 1027-1059

Li D S. Geological structure and hydrocarbon occurrence of Bohai Gulf oil and gas basin (China). Marine Geology \& Quaternary Geology. 1981. 1(1): 3-20 (in Chinese)

Li P L and Pang X Q. Formation of Subtle Reservoirs in Continental Rift Basins-A Case Study of the Jiyang Depression. Beijing: Petroleum Industry Press. 2001 (in Chinese)

Li P L. Oil/gas distribution patterns in Dongying Depression, Bohai Bay Basin. Journal of Petroleum Science and Engineering. 2004. 41(13): 57-66

Liu Z, Zhao Y, Du J H, et al. Characteristics of "multi-factor controlling and key factor entrapping" of formation and distribution of lithologic petroleum reservoirs in continental rift basin. Chinese Journal of Geology. 2006. 41(4): 612-635 (in Chinese)

Magoon L B and Dow W G. The petroleum system. In: The Petroleum System-From Source to Trap. AAPG Memoir 60. 1994. 3-24

McLeod A E, Underhill J R, Davies S J, et al. The influence of fault array evolution on synrift sedimentation patterns: Controls on deposition in the Strathspey-Brent-Statfjord Half Graben, Northern North Sea. 
AAPG Bulletin. 2002. 86(6): 1061-1093

Pang X Q. Modeling of Geological Processes. Beijing: Petroleum Industry Press. 2003. 314 (in Chinese)

Pang X Q, Qiu N S, Jiang Z X, et al. Modeling of Geology Processes. Beijing: Petroleum Industry Press. 2005. 293-284 (in Chinese)

Paton D A, van der Spuy D, Primio R D, et al. Tectonically induced adjustment of passive-margin accommodation space: influence on the hydrocarbon potential of the Orange Basin, South Africa. AAPG Bulletin. 2008. 92(5): 589-609

Qi J F, Deng R J, Zhou X H, et al. The structure of the Tanlu Fracture in the Cenozoic Basin of the Bohai Sea Area. Science in China (Series D: Earth Sciences). 2008. 38(1): 19-29 (in Chinese)

Su J B, Zhu W B, Wei J, et al. Fault growth and linkage: Implications for tectonosedimentary evolution in the Chezhen Basin of Bohai Bay, eastern China. AAPG Bulletin. 2011. 95(1): 1-26

Sun J, Zhan W H and Qiu X L. Relationship between tectonic evolution and petroleum systems in Baiyun Sag, Pearl River Mouth Basin. Marine Geology \& Quaternary Geology. 2011. 31(1): 101-107

Sun L T, Chen C M, Zhan W H, et al. Characteristics and influencing factors of fault sealing in Pearl River Mouth Basin. Acta Petrolei Sinica. 2007. 28(4): 36-41 (in Chinese)

Tang L J and Cui M. Structural deformation and fluid flow from East Sichuan to the northwestern periphery of the Xuefeng Uplift, China. Petroleum Science. 2012. 9(4): 429-435

Vakarelov B K and Bhattacharya J P. Local tectonic control on parasequence architecture: Second Frontier sandstone, Powder River Basin, Wyoming. AAPG Bulletin. 2009. 93(3): 295-327

Wang B, Zhu C R and Feng Y. Structure ridge and hydrocarbon migration pathway system of the Panyu Low Uplift in the Pearl River Mouth Basin. Offshore Oil. 2006. 26(1): 1-6

Xiang C F, Pang X Q, Yang W J, et al. Hydrocarbon migration and accumulation along the fault intersection zone - a case study on the reef-flat systems of the No.1 slope break zone in the Tazhong area, Tarim Basin. Petroleum Science. 2010. 7(2): 211-225

Xu G S, Ma R L, Gong D Y, et al. Features of the fault system and its relationship with migration and accumulation of hydrocarbon in Liaodong Bay. Petroleum Science. 2011. 8(3): 251-263

Yu J N, Zou H Y and Gong Z S. Preferential petroleum migration pathways in the eastern Pearl River Mouth Basin, offshore South China Sea. Journal of Earth Science. 2009. 20(4): 720-730

Zhao W Z, Zhu G Y, Su J, et al. Study on the multi-stage charging and accumulation model of Chinese marine petroleum: Example from eastern Lungu area in the Tarim Basin. Acta Petrologica Sinica. 2012. 28(3): 709-721 (in Chinese)

Zhu G Y, Jin Q, Dai J X, et al. Composite hydrocarbon-generation system: An important concept for source rock evaluation and hydrocarbon prediction in rift lacustrine basin. Chinese Journal of Geology. 2005. 40(1): 133-144 (in Chinese)

Zhu G Y, Yang H J, Su J, et al. New progress of marine hydrocarbon geological theory in China. Acta Petrologica Sinica. 2012. 28(3): 722-738 (in Chinese)

Zhu W L, Mi L J, Zhang H H, et al. Atlas of Oil and Gas Basins, China Sea. Beijing: Petroleum Industry Press. 2010. 93-95 (in Chinese)

Zou H Y, Gong Z S, Teng C Y, et al. Late-stage rapid accumulation of the PL19-3 giant oilfield in an active fault zone during Neotectonism in the Bozhong Depression, Bohai Bay. Science in China Earth Sciences. 2011. 54(3): 388-398

Zou Y C and Chen X K. Discussion on oil \& gas prospecting in the eastern Pearl River Mouth Basin from structural ridges study. China Offshore Oil and Gas (Geology). 1991. 3(2): 1-7 (in Chinese)

(Edited by Hao Jie) 